\title{
PENGARUH PENDIDIKAN GIZI DENGAN MEDIA KARTU KUARTET TERHADAP KEBIASAAN SARAPAN, ASUPAN ENERGI DAN PROTEIN SARAPAN, DAN PENGETAHUAN GIZI TENTANG SARAPAN DI SDN PEDURUNGAN KIDUL 01 DAN 02 KOTA SEMARANG
}

\section{THE EFFECT OF NUTRITIONAL EDUCATION WITH THE QUARTET CARD MEDIA ON BREAKFAST HABIT, ENERGY INTAKE AND BREAKFAST PROTEIN, AND BREAKFAST NUTRITION KNOWLEDGE IN PEDURUNGAN KIDUL SDN 01 AND 02 SEMARANG CITY}

\author{
Farida Rahmah ${ }^{1}$, Astidio Noviardhi ${ }^{2}$, Setyo Prihatin ${ }^{3}$, Cahyo Hunandar ${ }^{4}$, Ana Yuliah Rahmawati ${ }^{5}$ \\ ${ }^{1}$ Mahasiswa Jurusan Gizi Politeknik Kesehatan Kemenkes Semarang \\ 2,3,4,5 Dosen Jurusan Gizi Politeknik Kesehatan Kemenkes Semarang
}

\begin{abstract}
Background : Health education with the methods in games is more interesting than counseling methods in the classroom. The using of Quartet card media is the way as an alternative media to give information about the nutrition, which one using the game. Providing nutrition education through quartet card media is expected to increase breakfast habits, breakfast energy and protein intake and nutrition knowledge especially for elementary school.
\end{abstract}

Objectives : To determine the effect of nutrition education on quartet card media on breakfast habits, breakfast energy and protein intake and nutritional knowledge about breakfast in elementary school students. Method : This study used the quasy experiment method with a pre test, post test and control group design. The Sampling was done by randomly to get 26 treatment samples and 26 control samples at the Elementary School in Pedurungan Kidul 01 and 02 Semarang City. The data collected were sample identity card (name, age, gender, parental education, parental work), breakfast habits, breakfast energy and protein intake and nutritional knowledge about breakfast. Data was collected by interview and answering the questionnaire. The results of bivariate analysis using the Paired T-Test, Wilxocon, Independent T-Test and Mann Whitney test.

Results : There was an effect of increasing breakfast habits by an average of $1.71 \pm 0.58$, an increase in the amount of breakfast energy and protein intake and nutritional knowledge in the treatment group and a decrease in breakfast habits by an average of $-0.34 \pm 0.12$ in control group before and after providing nutrition education through quartet card media with a value of $p<0.05$.

Conclusion : Quartet card media about breakfast increases breakfast habits, breakfast energy and protein intake and nutritional knowledge in the treatment group.

Keywords : quartet cards media, breakfast, energy intake and breakfast protein, nutritional knowledge

\section{ABSTRAK}

Latar Belakang : Pendidikan kesehatan dengan permainan edukatif lebih menyenangkan dibandingkan penyuluhan metode di kelas. Media kartu kuartet sebagai alternatif media dalam penyampaian pesan gizi dengan mengutamakan unsur permainan. Pemberian pendidikan gizi melalui media kartu kuartet diharapkan dapat meningkatkan kebiasaan sarapan, asupan energi dan protein sarapan dan pengetahuan gizi khususnya bagi anak sekolah dasar.

Tujuan Penelitian : Mengetahui pengaruh pendidikan gizi dengan media kartu kuartet terhadap kebiasaan sarapan, asupan energi dan protein sarapan dan pengetahuan gizi tentang sarapan pada siswa Sekolah Dasar.

Metode Penelitian : Penelitian ini menggunakan metode quasy experiment dengan rancangan penelitian pre test post test with control group design. Pengambilan subjek penelitian dilakukan secara acak untuk mendapatkan 26 subjek penelitian perlakuan dan 26 subjek penelitian kontrol di SDN Pedurungan Kidul 01 dan 02 Kota Semarang. Data yang dikumpulkan yaitu data identitas subjek penelitian (nama, umur, jenis kelamin, 
pendidikan orang tua, pekerjaan orang tua), kebiasaan sarapan, asupan energi dan protein sarapan dan pengetahuan gizi tentang sarapan. Pengumpulan data dilakukan dengan metode wawancara langsung dan pengisian kuesioner. Hasil analisis bivariat dengan menggunakan uji Paired T-Test, Wilxocon, Independent T-Test dan Mann Whitney.

Hasil : Ada pengaruh peningkatan kebiasaan sarapan rata-rata sebesar $1,71 \pm 0,58$, peningkatan jumlah asupan energi dan protein sarapan dan pengetahuan gizi pada kelompok perlakuan dan terjadi penurunan kebiasaan sarapan rata-rata sebesar $-0,34 \pm 0,12$ pada kelompok kontrol sebelum dan sesudah pemberian pendidikan gizi melalui media kartu kuartet dengan nilai $p<0,05$.

Kesimpulan : Media kartu kuartet tentang sarapan meningkatkan kebiasaan sarapan, asupan energi dan protein sarapan dan pengetahuan gizi pada kelompok perlakuan.

Kata kunci : Media kartu kuartet, sarapan, asupan energi dan protein sarapan, pengetahuan gizi

\section{PENDAHULUAN}

Anak merupakan salah satu aset sumber daya manusia di masa depan yang perlu mendapat perhatian khusus. Salah satu upaya penting bagi kelangsungan hidup suatu bangsa adalah peningkatan dan perbaikan kualitas hidup anak. Kualitas hidup anak dapat dilihat melalui keadaan status gizi yang baik dan kualitas hidup anak yang baik merupakan salah satu indikator pembangunan yang harus dicapai dalam pembangunan negara. Status gizi anak merupakan salah satu tujuan yang akan dicapai dalam Sustainable Develompment Goals (SDGs). ${ }^{1}$

Salah satu upaya untuk memperoleh kesehatan dan gizi yang baik yaitu dengan membiasakan sarapan pagi. Sarapan pagi merupakan waktu makan yang sangat penting untuk anak sekolah, karena sarapan pagi memiliki banyak manfaat dan melatih anak untuk disiplin. ${ }^{2}$ Sarapan merupakan salah satu perilaku yang penting untuk mewudukan perilaku gizi seimbang dan merupakan salah satu dari 10 pesan gizi seimbang. ${ }^{19}$ Sementara penduduk Indonesia masih banyak yang belum membiasakan sarapan pagi. Berdasarkan Data Riset Kesehatan Dasar (Riskesdas) tahun 2018 menyatakan bahwa $26 \%$ anak Indonesia hanya mengkonsumsi minuman pada waktu sarapan, baik air putih, teh atau susu. Tak semua anak yang sarapan pagi pun sudah menerapkan pola sarapan pagi yang sehat dan seimbang. Terdapat 10,6 \% yang sarapannya mencukupi asupan energi sebesar $30 \%{ }^{3}$

Faktor-faktor yang mempengaruhi kebiasaan sarapan pada anak sekolah dasar menurut Laurence Green (2005) yaitu faktor predisposisi (pengetahuan, sikap dan jenis kelamin), faktor penguat (peraturan orang tua tentang sarapan) dan faktor pemungkin (uang saku, jarak rumah ke sekolah dan ketersediaan sarapan). ${ }^{4}$ Pendidikan gizi dengan menggunakan media yang menarik dan sesuai dengan karakteristik anak merupakan salah satu upaya yang dapat dilakukan untuk meningkatkan pengetahuan anak, khususnya mengenai sarapan.
Pendidikan kesehatan dengan permainan edukatif lebih menyenangkan dibandingkan dengan penyuluhan dengan metode pengajaran di kelas. Media kartu kuartet sebagai alternatif media dalam menyampaikan pesan gizi merupakan media yang mengutamakan unsur permainan. ${ }^{5}$ Media kuartet gizi dapat memperjelas suatu permasalahan dengan melihat gambar dan sesuai dengan pokok bahasan, serta menimbulkan kreativitas siswa dalam membahasakannya. ${ }^{6}$

Tujuan penelitian ini untuk mengetahui pengaruh pendidikan gizi dengan media kartu kuartet terhadap kebiasaan sarapan, asupan energi dan protein sarapan dan pengetahuan gizi tentang sarapan pada siswa sekolah dasar.

\section{METODE}

Penelitian ini merupakan penelitian quasy experiment design dan rancangan penelitian ini adalah pre test post test control group design. Pada penelitian ini, subjek yang memenuhi kriteria inklusi dikelompokkan menjadi 2, yaitu kelompok perlakuan (diberi media kartu kuartet dan ceramah) dan kelompok kontrol (diberi ceramah).

Penelitian dilakukan di SDN Pedurungan Kidul 01 dan 02 Kota Semarang dengan populasi 127 siswa. Subjek dalam penelitian ini adalah siswa kelas $\mathrm{V}$, tidak dalam keadaan sakit dan bersedia menjadi subjek penelitian. Kelompok sampel dan kelompok perlakuan terdapat dalam 1 sekolahan yang sama. Perhitungan besar subjek penelitian menggunakan rumus Lameshow dan didapatkan subjek penelitian sebanyak 52 subjek penelitian pada masing masing kelompok. Namun setelah dilakukan penelitian terdapat 4 siswa yang drop out dikarenakan sakit, sehingga subjek penelitian penelitian ini sebanyak 48 siswa dengan rincian 24 siswa kelompok perlakuan dan 24 siswa kelompok kontrol. Penelitian ini dilakukan selama 4 minggu dengan diberikan pendidikan gizi sebanyak 2 kali. 
Kelompok perlakuan dalam penelitian ini diberi pendidikan gizi dengan media kartu kuartet dan ceramah sebanyak 2 kali dalam dua minggu dengan durasi tiap pertemuan 30 menit. Kegiatan pendidikan gizi dengan media kartu kuartet terbagi menjadi 7 kelompok degan masing-masing kelompok terdiri dari 4 siswa. Kegiatan ini dimonitoring oleh peneliti dan dibantu oleh 6 enumerator yang telah memahami materi yang disampaikan, sedangkan kelompok kontrol hanya diberikan pendidikan gizi dengan ceramah. Kelompok data yang dianalisis adalah pendidikan gizi dengan media kartu kuartet sebagai variabel independent, sedangkan kebiasaan sarapan, asupan energi dan protein sarapan dan pengetahuan gizi tentang sarapan sebagai variabel dependent. Data asupan energi dan protein diperoleh dengan Recall 24 jam dan data pengetahuan gizi diperoleh dengan cara wawancara kepada subjek penelitian . Data pendidikan dikategorikan menjadi 2, yaitu rendah untuk tingkat pendidikan SD - SMP dan tinggi untuk tingkat pendidikan SMA - Perguruan Tinggi. ${ }^{20}$

Instrumen yang digunakan terdiri dari formulir persetujuan subjek penelitian, formulir identitas subjek penelitian, kuesioner kebiasaan sarapan, formulir recall sarapan, kuesioner pengetahuan gizi tentang sarapan dan media kartu kuartet. Data diukur sebelum dan sesudah intervensi. Analisis univariat digunakan untuk mendiskripsikan data variabel yang diteliti dalam bentuk tabulasi silang. Analisis bivariat digunakan untuk mengetahui perbedaan skor kebiasaan sarapan, asupan energi dan protein sarapan, dan pengetahuan gizi tentang sarapan sebelum dan sesudah intervensi pada kelompok perlakuan dan kelompok kontrol menggunakan uji Paired T-test dan uji Wilxocon. Sedangkan untuk mengetahui perbedaan selisih kebiasaan sarapan, asupan energi dan protein sarapan, dan pengetahuan gizi tentang sarapan antara kedua kelompok dengan uji Independent T-test dan uji Mann Whitney jika data berdistribusi normal, apabila data tidak berdistribusi normal menggunakan uji Wilcoxon dengan tingkat kemaknaan $\mathrm{p}<0,05$.

\section{HASIL DAN PEMBAHASAN}

Penelitian ini dilaksanakan di SDN Pedurungan Kidul 01 dan 02 Kota Semarang, sebanyak 2 kali intervensi. Jumlah subjek penelitian ini sebanyak 48 siswa, 24 siswa pada kelompok perlakuan dan 24 siswa pada kelompok kontrol.

\section{Karakteristik Subjek Penelitian}

Deskripsi karakteristik subjek penelitian penelitian pada kelompok perlakuan dan kelompok kontrol dapat dilihat pada tabel 1.
Tabel 1. Distribusi Subjek penelitian Kelompok Perlakuan dan Kelompok Kontrol Menurut Umur dan Jenis Kelamin pada Siswa SDN Pedurungan Kidul 01 dan 02 Kota Semarang

\begin{tabular}{|c|c|c|c|c|}
\hline \multirow{3}{*}{ Variabel } & \multicolumn{4}{|c|}{ Kelompok } \\
\hline & \multicolumn{2}{|c|}{$\begin{array}{c}\text { Perlakuan } \\
(n=24)\end{array}$} & \multicolumn{2}{|c|}{ Kontrol $(n=24)$} \\
\hline & $\mathbf{n}$ & $\%$ & $\mathbf{n}$ & $\%$ \\
\hline \multicolumn{5}{|l|}{ Umur } \\
\hline 10 & 9 & 37,5 & 7 & 29,2 \\
\hline 11 & 13 & 52,2 & 16 & 66,7 \\
\hline 12 & 2 & 8,3 & 1 & 4,2 \\
\hline \multicolumn{5}{|l|}{ Jenis Kelamin } \\
\hline Laki-laki & 11 & 45,8 & 12 & 50 \\
\hline Perempuan & 13 & 52,4 & 12 & 50 \\
\hline \multicolumn{5}{|l|}{ Pekerjaan Ayah } \\
\hline Non Pegawai & 12 & 50 & 6 & 25 \\
\hline Pegawai & 12 & 50 & 18 & 75 \\
\hline \multicolumn{5}{|l|}{ Pekerjaan Ibu } \\
\hline Non Pegawai & 15 & 62,5 & 10 & 41,7 \\
\hline Pegawai & 9 & 37,5 & 14 & 58,3 \\
\hline \multicolumn{5}{|l|}{ Pendidikan } \\
\hline \multicolumn{5}{|l|}{ Ayah } \\
\hline Rendah & 8 & 33,3 & 3 & 12,5 \\
\hline Tinggi & 16 & 66,7 & 21 & 87,5 \\
\hline \multicolumn{5}{|l|}{ Pendidikan Ibu } \\
\hline Rendah & 9 & 37,5 & 2 & 8,3 \\
\hline Tinggi & 15 & 62,5 & 22 & 91,7 \\
\hline
\end{tabular}

a. Umur

Berdasarkan tabel 1 dapat dilihat bahwa pada kelompok perlakuan dan kelompok kontrol subjek penelitian terbanyak adalah berumur 11 tahun sebanyak 13 (52,2\%) subjek penelitian kelompok perlakuan dan $16(66,7 \%)$ subjek penelitian kelompok kontrol.

\section{b. Jenis Kelamin}

Berdasarkan tabel 1 dapat dilihat bahwa pada kelompok perlakuan subjek penelitian terbanyak adalah perempuan yaitu 13 (52,4\%) dan pada kelompok kontrol laki-laki dan perempuan sama yaitu sebanyak 12 (50\%).

\section{c. Pekerjaan Ayah}

Berdasarkan tabel 2, dapat dilihat bahwa pada kelompok perlakuan dan kelompok kontrol pekerjaan ayah dengan jumlah tertinggi yaitu non pegawai dan pegawai sebanyak 12 (50\%) pada kelompok perlakuan 18 (75\%) pada kelompok kontrol.

\section{d. Pekerjaan Ibu}

Berdasarkan tabel 2, dapat dilihat bahwa pada kelompok perlakuan pekerjaan ibu dengan jumlah tertinggi yaitu non pegawai sebanyak 
15 (62,5\%) pada kelompok perlakuan dan pegawai 14 (58,3\%) pada kelompok kontrol.

\section{e. Pendidikan Ayah}

Berdasarkan tabel 2, dapat dilihat bahwa pada kelompok perlakuan dan kelompok kontrol pendidikan ayah dengan jumlah tertinggi yaitu tinggi sebanyak 16 (66,7\%) pada kelompok perlakuan dan $21(87,5 \%)$ pada kelompok kontrol.

\section{f. Pendidikan Ibu}

Berdasarkan tabel 2, dapat dilihat bahwa pada kelompok perlakuan dan kelompok kontrol pendidikan ibu dengan jumlah tertinggi yaitu SMA / Perguruan Tinggi sebanyak 15 (62,5\%) pada kelompok perlakuan dan 22 (91,7\%) pada kelompok kontrol.

2. Pengaruh Pendidikan Gizi dengan Media Kartu Kuartet terhadap Kebiasaan Sarapan pada Siswa Sekolah Dasar antara Kelompok Perlakuan dan Kelompok Kontrol

Hasil penelitian terkait perbandingan ratarata (rerata) kebiasaan sarapan sebelum dan sesudah diberikan intervensi pada kelompok perlakuan dan kelompok kontrol dapat dilihat pada gambar 1 .

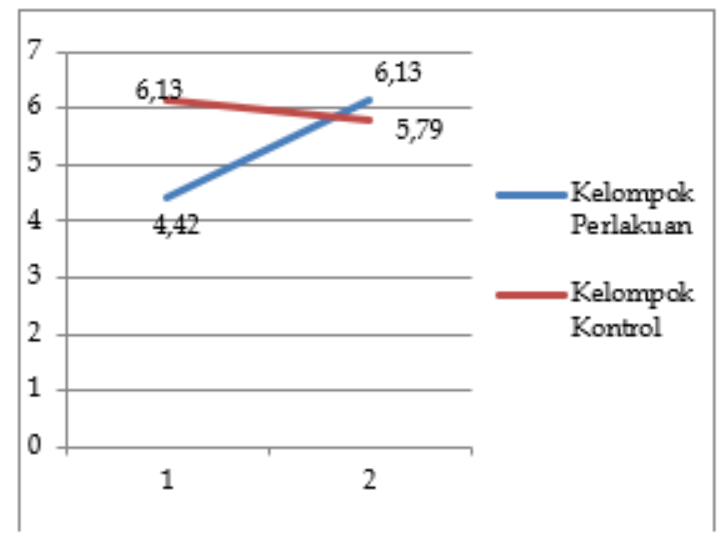

Gambar 1. Grafik Perbandingan rata-rata Kebiasaan Sarapan Sebelum dan Sesudah Intervensi

Berdasarkan analisis gambar 1, menunjukkan bahwa kelompok perlakuan mengalami peningkatan rata-rata kebiasaan sarapan sebelum dan setelah diberikan intervensi. Sedangkan pada kelompok kontrol rata-rata kebiasaan sarapan mengalami penurunan sebelum dan setelah intervensi. Hasil penelitian terkait pengaruh pendidikan gizi dengan media kartu kuartet terhadap kebiasaan sarapan pada siswa sekolah dasar pada kelompok perlakuan dan kelompok kontrol dapat dilihat pada tabel 2 .

Tabel 2. Pengaruh Pendidikan Gizi dengan Media Kartu Kuartet terhadap Kebiasaan Sarapan pada Siswa Sekolah Dasar antara Kelompok Perlakuan dan Kelompok Kontrol

\begin{tabular}{|c|c|c|c|c|}
\hline \multirow{2}{*}{$\begin{array}{c}\text { Kebiasaan } \\
\text { Sarapan }\end{array}$} & \multicolumn{2}{|c|}{$\begin{array}{c}\text { Kelompok } \\
\text { Perlakuan } \\
(n=24)\end{array}$} & \multicolumn{2}{|c|}{$\begin{array}{c}\text { Kelompok Kontrol } \\
(\mathbf{n}=24)\end{array}$} \\
\hline & $\begin{array}{c}\text { Mean } \pm S \\
\text { D }\end{array}$ & $\begin{array}{c}p \\
\text { value }\end{array}$ & $\begin{array}{c}\text { Mean } \pm S \\
\text { D }\end{array}$ & p value \\
\hline Sehelum & $4,42 \pm 2$ & & $6,13 \pm 1,5$ & \\
\hline Sesudah & $\begin{array}{c}06 \\
6,13 \pm 1 \\
48\end{array}$ & 0,001 & $\begin{array}{c}4 \\
5,79 \pm 1,6 \\
2 \\
\end{array}$ & $0,370^{* *}$ \\
\hline $\begin{array}{l}\Delta \\
\text { Kebiasaan } \\
\text { Sarapan }\end{array}$ & $\begin{array}{l}1,71 \pm 0 \\
58\end{array}$ & & $\begin{array}{c}- \\
0,34 \pm 0,1 \\
2\end{array}$ & $0,001^{* *}$ \\
\hline
\end{tabular}

Perhitungan statistik rata-rata kebiasaan sarapan sebelum dan sesudah menunjukkan bahwa pada kelompok perlakuan mengalami peningkatan rata-rata sebesar $1,71 \pm 0,58$. Hasil uji statistik menunjukkan $p$ value $=0,001^{*}(<0,05)$ yang berarti pendidikan gizi dengan media kartu kuartet sarapan dan ceramah dapat meningkatkan kebiasaan sarapan pada siswa. Berbeda dengan kelompok kontrol, hasil kebiasaan sarapan mengalami penurunan ratarata antara sebelum dan sesudah sebesar $0,34 \pm 0,12$, yang menunjukkan $p$ value $=0,370^{* *}$ $(>0,05)$ yang berarti pada kelompok kontrol tidak terjadi perubahan yang signifikan setelah diberikan pendidikan gizi dengan ceramah. Berdasarkan uji statistik antar kelompok menunjukkan $p$ value $=0,001^{* * *}$ yang menyatakan bahwa ada pengaruh pemberian pendidikan gizi dengan media kartu kuartet dan ceramah dibandingkan dengan ceramah antara kelompok perlakuan dan kelompok kontrol.

Penelitian Sartika mengenai penerapan komunikasi, informasi dan edukasi gizi terhadap perilaku sarapan siswa sekolah dasar menunjukkan peningkatan skor rata-rata perilaku siswa terhadap kebiasaan sarapan. KIE gizi bagi anak sekolah dapat membentuk kebiasaan makan anak sejak dini agar dapat menjadi individu yang lebih baik di masa mendatang dan dapat mengubah sikap dan perilaku anak menjadi terbiasa sarapan. ${ }^{7}$ Sejalan dengan penelitian Nindrea yang dilakukan pada anak sekolah dasar kelas IV dan V menyatakan/menunjukkan bahwa terdapat pengaruh penyuluhan gizi dengan peningkatan rata-rata perilaku sarapan pagi sebelum dan sesudah dengan $p=0,001(p<0,05){ }^{8}$ 
Penelitian yang dilakukan oleh Maduretno menyatakan bahwa adanya pengaruh yang signifikan antara pemberian pendidikan gizi terhadap peningkatan niat dan perilaku kebiasaan sarapan. ${ }^{9}$

Berdasarkan analisis penelitian ini, pendidikan gizi dengan media kartu kuartet sarapan merupakan stimulus yang diharapkan dapat memberikan pengaruh pada siswa untuk memiliki sikap dan perilaku sesuai dengan pesan dari media ini. Dalam penelitian ini, jika dilihat dari analisis metode yang digunakan dalam pendidikan gizi, dengan metode pendidikan gizi media kartu kuartet tentang sarapan dapat mempengaruhi perilaku seseorang dalam sarapan pagi.

3. Pengaruh Pendidikan Gizi dengan Media Kartu Kuartet terhadap Asupan Energi Sarapan pada Siswa Sekolah Dasar antara Kelompok Perlakuan dan Kelompok Kontrol

Hasil penelitian terkait perbandingan rata-rata asupan energi sarapan sebelum dan sesudah diberikan intervensi pada kelompok perlakuan dan kelompok kontrol dapat dilihat pada gambar 2

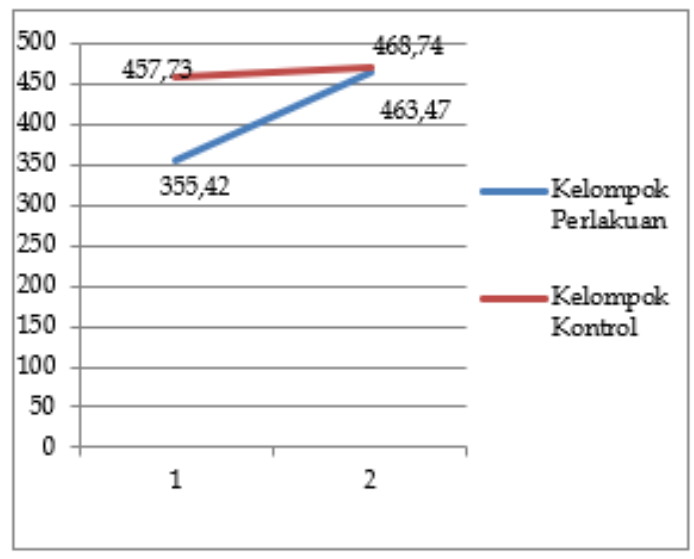

Gambar 2. Grafik Perbandingan Rata-rata

Asupan Energi Sarapan Sebelum dan Sesudah Intervensi

Berdasarkan gambar 2, dapat dilihat bahwa kelompok perlakuan dan kelompok kontrol mengalami peningkatan rata-rata asupan energi sarapan sebelum dan setelah diberikan intervensi. Namun pada kelompok perlakuan mengalami peningkatan rata-rata asupan energi sarapan lebih tinggi daripada kelompok kontrol antara sebelum dan sesudah diberikan intervensi. Hasil penelitian terkait pengaruh pendidikan gizi dengan media kartu kuartet terhadap asupan energi sarapan pada siswa sekolah dasar pada kelompok perlakuan dan kelompok kontrol dapat dilihat pada tabel 4.

Tabel 4. Pengaruh Pendidikan Gizi dengan Media Kartu Kuartet terhadap Asupan Energi Sarapan pada Siswa Sekolah Dasar antara Kelompok Perlakuan dan Kelompok Kontrol

\begin{tabular}{|c|c|c|c|c|}
\hline \multirow{2}{*}{$\begin{array}{c}\text { Asupan } \\
\text { Energi } \\
\text { Sarapan }\end{array}$} & \multicolumn{2}{|c|}{$\begin{array}{c}\text { Kelompok } \\
\text { Perlakuan }(n=24)\end{array}$} & \multicolumn{2}{|c|}{$\begin{array}{c}\text { Kelompok Kontrol } \\
(n=24)\end{array}$} \\
\hline & $\begin{array}{l}\text { Mean } \pm \\
\text { SD }\end{array}$ & $\begin{array}{c}p \\
\text { value }\end{array}$ & $\begin{array}{l}\text { Mean } \pm \\
\text { SD }\end{array}$ & $\begin{array}{c}p \\
\text { value }\end{array}$ \\
\hline \multirow{2}{*}{ Sebelum } & $355,42 \pm 8$ & & $457,73 \pm 15$ & \\
\hline & 1,75 & 0,000 & 1,18 & 0,587 \\
\hline Sesudah & $\begin{array}{c}463,47 \pm 1 \\
04,92\end{array}$ & & $\begin{array}{c}468,74 \pm 12 \\
9,60\end{array}$ & "* \\
\hline \multicolumn{5}{|l|}{$\Delta$} \\
\hline Asupan & $108,05 \pm 2$ & & $11,01 \pm 21,5$ & 0,011 \\
\hline $\begin{array}{l}\text { Energi } \\
\text { Sarapan }\end{array}$ & 3,17 & & 8 & $\cdots$ \\
\hline
\end{tabular}

Berdasarkan perhitungan statistik ratarata asupan energi sarapan sebelum dan sesudah intervnesi menunjukkan bahwa pada kelompok perlakuan mengalami peningkatan rata-rata sebesar $108,05 \mathrm{kkal} \pm 23,17$. Hasil uji statistik menunjukkan $p$ value $=0,000^{*}(<0,05)$ yang berarti pendidikan gizi dengan media kartu kuartet dan ceramah dapat meningkatkan asupan energi sarapan pada siswa. Hasil rata-rata asupan energi sarapan pada kelompok kontrol mengalami peningkatan antara sebelum dan sesudah sebesar 11,02 kkal $\pm 21,58$ yang menunjukkan $p$ value $=$ $0,587^{* *}(>0,05)$ yang berarti pada kelompok kontrol tidak terjadi perubahan yang signifikan dengan diberikan pendidikan gizi dengan metode ceramah. Uji statistik antar kelompok menunjukkan $p$ value $=0,011^{* * *}$ yang menyatakan bahwa ada pengaruh pemberian pendidikan gizi dengan media kartu kuartet dan ceramah dibandingkan dengan ceramah antara kelompok perlakuan dan kelompok kontrol.

Peningkatan asupan energi sejalan dengan penelitian Anzarkusuma yang menyatakan bahwa perubahan sikap dipengaruhi beberapa faktor yaitu pengalaman pribadi, lingkungan, pengaruh orang lain, pengaruh kebudayaan, media massa, dan faktor emosional. Dikaitkan dengan keingintahuan anak usia sekolah dasar yang lebih tinggi dibanding usia dewasa, menyebabkan perubahan pola makan pada anak mudah berubah. ${ }^{10}$

Asupan energi sarapan yang baik harus mengandung sumber energi sebesar $\geq 500$ kkal. ${ }^{11}$ Hasil analisis penelitian ini, masih ditemukan subjek dengan kategori asupan energi sarapan kurang (<500 kkal) sebanyak 14 (58,3\%) siswa 
pada kelompok perlakuan dan 13 (54,2\%) siswa pada kelompok kontrol dikarenakan rendahnya sumber karbohidrat dan ragam jenis pangan saat sarapan, padahal zat gizi yang cukup hanya dapat dipenuhi dari makanan yang beragam. Perdana dan Hardinsyah menyatakan sarapan akan memberikan kontribusi zat gizi yang diperlukan tubuh, seperti protein, lemak, vitamin dan mineral. Ketersediaan zat gizi ini penting untuk berfungsinya proses fisiologis dalam tubuh. ${ }^{12}$

Sarapan sangat penting untuk anak usia sekolah karena dengan sarapan kebutuhan zat gizi untuk menunjang aktivitas pada saat disekolah dapat terpenuhi. Dengan terpenuhinya kebutuhan zat gizi maka konsentrasi belajar siswa juga akan meningkat dan tidak akan mengganggu pertumbuhanya. Hal ini akan mempengaruhi performa akademiknya. ${ }^{13}$

4. Pengaruh Pendidikan Gizi dengan Media Kartu Kuartet terhadap Asupan Protein Sarapan pada Siswa Sekolah Dasar antara Kelompok Perlakuan dan Kelompok Kontrol

Hasil penelitian terkait perbandingan rata-rata asupan protein sarapan sebelum dan sesudah diberikan intervensi pada kelompok perlakuan dan kelompok kontrol dapat dilihat pada gambar 3 .

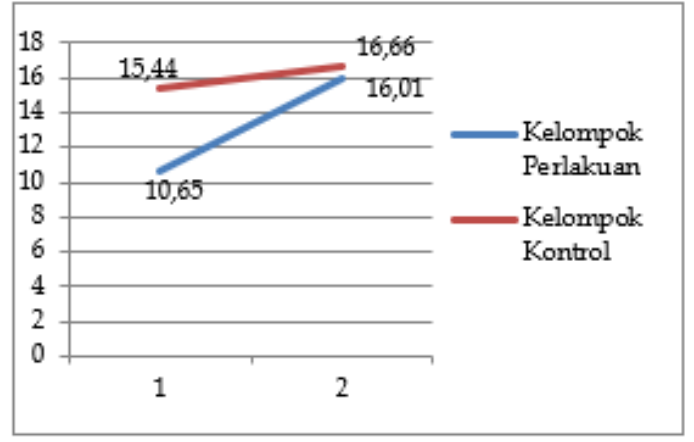

Gambar 3. Grafik Perbandingan Rata-rata Asupan Protein Sarapan Sebelum dan Sesudah Intervensi

Berdasarkan gambar 3, menunjukkan bahwa kelompok perlakuan dan kelompok kontrol mengalami peningkatan rata-rata asupan protein sarapan sebelum dan setelah diberikan intervensi. Namun pada kelompok perlakuan mengalami peningkatan rata-rata asupan protein sarapan lebih tinggi daripada kelompok kontrol antara sebelum dan sesudah diberikan intervensi. Hasil penelitian terkait pengaruh pendidikan gizi dengan media kartu kuartet terhadap asupan protein sarapan pada siswa sekolah dasar pada kelompok perlakuan dan kelompok kontrol dapat dilihat pada tabel 5 .
Tabel 5. Pengaruh Pendidikan Gizi dengan Media Kartu Kuartet terhadap Asupan Protein Sarapan pada Siswa Sekolah Dasar antara Kelompok Perlakuan dan Kelompok Kontrol

\begin{tabular}{|c|c|c|c|c|}
\hline \multirow{2}{*}{$\begin{array}{l}\text { Asupan } \\
\text { Protein } \\
\text { Sarapan }\end{array}$} & \multicolumn{2}{|c|}{$\begin{array}{c}\text { Kelompok } \\
\text { Perlakuan }(n=24) \\
\end{array}$} & \multicolumn{2}{|c|}{$\begin{array}{c}\text { Kelompok Kontrol } \\
(n=24)\end{array}$} \\
\hline & $\begin{array}{l}\text { Mean } \pm \\
\text { SD }\end{array}$ & $\begin{array}{c}p \\
\text { value }\end{array}$ & $\begin{array}{c}\text { Mean } \pm \\
\text { SD }\end{array}$ & $\begin{array}{c}p \\
\text { value }\end{array}$ \\
\hline Sehelum & $10,65 \pm 2$ & & $15,44 \pm 5,8$ & \\
\hline Sesudah & $\begin{array}{c}70 \\
16,01 \pm 4 \\
47\end{array}$ & 0,000 & $\begin{array}{c}4 \\
16,66 \pm 4,9 \\
8\end{array}$ & $0,375^{* *}$ \\
\hline$\Delta$ & & & & \\
\hline $\begin{array}{l}\text { Asupan } \\
\text { Protein } \\
\text { Sarapan }\end{array}$ & $\begin{array}{c}5,36 \pm 1,7 \\
7\end{array}$ & & $1,22 \pm 0,86$ & $0,008^{* *}$ \\
\hline
\end{tabular}

Perhitungan statistik rata-rata asupan protein sebelum dan sesudah menunjukkan bahwa pada kelompok perlakuan mengalami peningkatan rata-rata sebesar 5,36 gram $\pm 1,77$. Hasil uji statistik menunjukkan $p$ value $=0,000^{*}$ $(<0,05)$ yang berarti pendidikan gizi dengan media kartu kuartet sarapan dan ceramah dapat meningkatkan asupan protein sarapan pada siswa. Pada kelompok kontrol hasil rata-rata asupan protein sarapan juga mengalami peningkatan antara sebelum dan sesudah sebesar 1,22 gram $\pm 0,86$, dengan hasil uji statistik menunjukkan $p$ value $=0,375^{* *}(>0,05)$ yang berarti pada kelompok kontrol tidak terjadi perubahan yang signifikan setelah diberikan pendidikan gizi dengan ceramah. Berdasarkan uji statistik antar kelompok menunjukkan $p$ value = $0,008^{* * *}$ yang menyatakan bahwa ada pengaruh pemberian pendidikan gizi dengan media kartu kuartet dan ceramah dibandingkan dengan ceramah antara kelompok perlakuan dan kelompok kontrol.

Penelitian Gambir menyatakan bahwa asupan protein meningkat setelah diberikan edukasi gizi dan perubahan yang lebih tinggi ditemukan pada kelompok perlakuan (permainan bola pintar) dibandingkan dengan kelompok kontrol (penyuluhan). ${ }^{14}$ Makanan pada anak sekolah harus diperhatikan zat gizinya terutama protein untuk membantu proses pertumbuhan tinggi badan serta untuk pertumbuhan otak dan kecerdasan. Protein merupakan zat gizi yang penting bagi tubuh, karena berfungsi sebagai zat pembangun dan pengatur, protein adalah sumber asam amino yang mengandung unsur $\mathrm{C}, \mathrm{H}, \mathrm{O}$ dan $\mathrm{N}$ yang tidak dimiliki oleh lemak dan karbohidrat. Anak-anak yang sulit makan atau tidak mau makan dapat mempengaruhi pertumbuhan mereka. Sarapan pagi dengan makanan yang 
beraneka ragam akan memenuhi kebutuhan gizi untuk mempertahankan kesegaran tubuh dan meningkatkan produktivitas kerja. Pada anakanak dengan sarapan pagi akan memudahkan konsentrasi belajar. ${ }^{15}$

Hasil analisis penelitian ini menunjukkan bahwa rata-rata asupan protein pada kelompok perlakuan maupun kelompok kontrol sudah memenuhi kebutuhan protein sarapan $(\geq 9,8$ gram), tetapi masih ditemukan subjek dengan kategori asupan protein kurang sebanyak 4 $(16,6 \%)$ siswa pada kedua kelompok. Asupan protein yang sering dikonsumsi saat sarapan yaitu telur, ayam, ikan, tempe, tahu dan susu. Namun peningkatan rata-rata asupan protein sarapan pada kelompok perlakuan lebih tinggi daripada kelompok kontrol. Hal ini menunjukkan bahwa dengan pendidikan gizi menggunakan media kartu kuartet sarapan dapat meningkatkan asupan protein sarapan pada kelompok perlakuan, dibandingkan pendidikan gizi menggunakan metode ceramah pada kelompok kontrol.

5. Pengaruh Pendidikan Gizi dengan Media Kartu Kuartet terhadap Pengetahuan Gizi tentang Sarapan pada Siswa Sekolah Dasar antara Kelompok Perlakuan dan Kelompok Kontrol Hasil penelitian terkait pengaruh pendidikan gizi dengan media kartu kuartet terhadap pengetahuan tentang sarapan pada siswa sekolah dasar pada kelompok perlakuan dan kelompok kontrol dapat dilihat pada gambar 4.

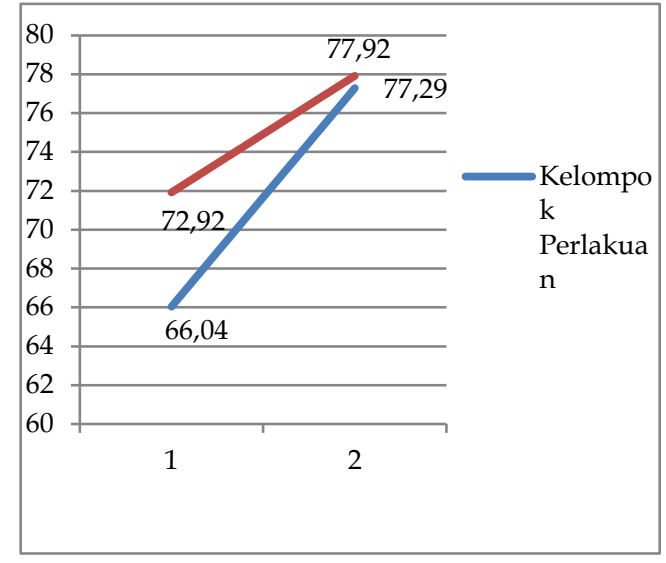

Gambar 4. Grafik Perbandingan Rata-rata Skor Pengetahuan Gizi Sebelum dan Sesudah Intervensi

Berdasarkan gambar 4, dapat dilihat bahwa kelompok perlakuan dan kelompok kontrol sama-sama mengalami peningkatan ratarata skor pengetahuan sebelum dan setelah diberikan intervensi. Pada kelompok perlakuan peningkatan rata-rata skor pengetahuan meningkat lebih tinggi dibandingkan dengan kelompok kontrol. Hasil uji statistik mengenai pengaruh pendidikan gizi dengan media kartu kuartet terhadap pengetahuan tentang sarapan pada siswa sekolah dasar pada kelompok perlakuan dan kelompok kontrol dapat dilihat pada tabel 6 :

Tabel 6. Pengaruh Pendidikan Gizi dengan Media Kartu Kuartet terhadap Pengetahuan Gizi tentang Sarapan pada Siswa Sekolah Dasar antara Kelompok Perlakuan dan Kelompok Kontrol

\begin{tabular}{|c|c|c|c|c|}
\hline \multirow{2}{*}{ Pengetahuan } & \multicolumn{2}{|c|}{$\begin{array}{c}\text { Kelompok } \\
\text { Perlakuan }(n=24)\end{array}$} & \multicolumn{2}{|c|}{$\begin{array}{c}\text { Kelompok } \\
\text { Kontrol }(n=24)\end{array}$} \\
\hline & $\begin{array}{c}\text { Mean } \pm \\
\text { SD }\end{array}$ & $\begin{array}{c}p \\
\text { value }\end{array}$ & $\begin{array}{c}\text { Mean } \pm \\
\text { SD }\end{array}$ & $\begin{array}{c}p \\
\text { value }\end{array}$ \\
\hline \multirow{2}{*}{ Sebelum } & $66,04 \pm 6$ & \multirow{4}{*}{$0,000^{*}$} & $72,92 \pm$ & \\
\hline & 91 & & 5,88 & $0,000^{\circ}$ \\
\hline \multirow{2}{*}{ Sesudah } & $77,29 \pm 4$ & & $77,92 \pm$ & \\
\hline &, 42 & & 4,40 & \\
\hline$\Delta$ & $11,25 \pm 2$ & & $5,00 \pm 1$ & $0,001^{\circ}$ \\
\hline Pengetahuan &, 49 & &, 48 & $*$ \\
\hline
\end{tabular}

Berdasarkan uji statistik rata-rata skor pengetahuan sebelum dan sesudah pada kelompok perlakuan menunjukkan bahwa terjadi peningkatan rata-rata sebesar $11,25 \pm 2,49$ poin. Hasil uji statistik menunjukkan $p$ value $=0,000^{*}$ $(<0,05)$ yang berarti pendidikan gizi dengan menggunakan media kartu kuartet sarapan dan ceramah dapat meningkatkan pengetahuan siswa. Hasil pengetahuan pada kelompok kontrol juga mengalami peningkatan, dimana rata-rata selisih pengetahuan pada kelompok kontrol antara sebelum dan sesudah terjadi kenaikan sebesar $5,00 \pm 1,48$ poin yang menunjukkan $p$ value $=0,000^{* *}(<0,05)$ yang berarti pendidikan gizi dengan menggunakan media ceramah dapat meningkatkan pengetahuan siswa. Berdasarkan uji statistik antar kelompok menunjukkan $p$ value $=0,001^{* * *}$ yang menyatakan bahwa ada pengaruh pemberian pendidikan gizi dengan media kartu kuartet dan ceramah dibandingkan dengan ceramah antara kelompok perlakuan dan kelompok kontrol.

Hasil penelitian menunjukkan bahwa pada saat pre-test kelompok perlakuan dan kelompok kontrol pada pertanyaan tentang piring makanku, syarat sarapan yang sehat, manfaat sarapan, dampak sarapan, tips membiasakan sarapan dan contoh menu sarapan masih rendah, tetapi pada saat post-test kelompok perlakuan terjadi peningkatan skor pengetahuan lebih tinggi daripada kelompok kontrol. Dimana kelompok perlakuan setelah mendapatkan pendidikan gizi 
dengan media kartu kuartet mampu menjawab dengan benar. Secara umum dapat dikatakan bahwa siswa sekolah dasar dalam penelitian ini memahami materi tentang sarapan.

Penelitian ini sejalan dengan Wahyuningsih, dkk yang dilakukan pada siswa kelas $\mathrm{V}$ menunjukkan bahwa edukasi gizi dengan media nutrition card dapat meningkatkan pengetahuan. Perbedaan rata-rata setelah diberikan intervensi dengan media nutrition card terjadi peningkatan rata-rata skor pengetahuan sebesar 8,92 $\pm 0,99$ dan berdasarkan uji statistik menunjukkan terdapat perbedaan tingkat pengetahuan yang signifikan dengan $p$ value $=$ $0,001(p<0,05) \cdot{ }^{16}$ Penelitian Fadhilah, dkk pada siswa kelas $\mathrm{V}$ menunjukkan bahwa terdapat pengaruh yang berarti dalam pemberian penyuluhan dengan media kartu sayuran terhadap tingkat pengetahuan siswa tentang sayuran dengan $p$ value $=0,000<0,05 .{ }^{17}$

Salah satu permasalahan dalam keefektifan pemberian informasi adalah kurangnya minat dalam penyerapan informasi. Minat merupakan faktor penting yang harus ditingkatkan sebelum pemberian informasi. Salah satu cara agar minat dalam menerima informasi meningkat yaitu menggunakan media dalam proses pemberian informasi. Pemberian informasi yang efektif untuk anak Sekolah Dasar salah satunya adalah dengan menggunakan media pembelajaran dengan metode belajar sambil bermain. ${ }^{17}$

Hasil penelitian Khairunnisak mengenai penggunaan media kartu sebagai strategi dalam pembelajaran membaca permulaan menyatakan bahwa proses belajar mengajar dengan metode belajar sambil bermain menggunakan media pembelajaran lebih efektif dibandingkan dengan metode ceramah karena siswa lebih aktif dalam proses penyerapan informasi karena siswa dapat melihat media, memegang media, membaca, mendengar, menyimpulkan materi dan lebih aktif dalam tanya jawab. ${ }^{18}$ Pengetahuan merupakan hasil dari tahu, dan akan terjadi setelah seseorang melakukan penginderaan terhadap suatu objek tertentu. Semakin banyak indera yang digunakan maka semakin tinggi tingkat penyerapan informasi. ${ }^{18}$

Kartu kuartet sarapan merupakan media yang berisi informasi mengenai pentingnya sarapan. Pesan yang ada dalam kartu kuartet sarapan didukung dengan gambar sesuai dengan topik pada masing-masing kartu, warna kartu, bentuk kartu, dan tekstur kertas jenis doft yang tebal sehingga menarik untuk dimainkan. Metode pendidikan gizi yang menarik dan menciptakan situasi menyenangkan menjadi faktor pendukung timbulnya keinginan untuk memainkannya. Dalam permainan kartu kuartet, setiap peserta berusaha mengumpulkan sebanyak mungkin set kartu dengan topik yang sama. Oleh karena itu, dengan permainan kartu kuartet sarapan dapat menjadi salah satu upaya untuk meningkatkan pengetahuan siswa mengenai pentingnya sarapan.

Berdasarkan hasil pengamatan dalam penelitian ini menunjukkan pada kelompok perlakuan yang diberikan pendidikan gizi dengan media kartu kuartet, siswa lebih tertarik dan antusias selama memainkan kartu. Sedangkan pada kelompok kontrol yang diberikan pendidikan gizi dengan metode ceramah siswa tidak konsentrasi mendengarkan ceramah dan cepat bosan karena hanya mendengarkan saja. Hal tersebut dapat mempengaruhi informasi yang diperoleh menjadi berkurang dan mempengaruhi hasil pengetahuan yang diperoleh.

\section{KESIMPULAN}

Ada pengaruh pendidikan gizi dengan media kartu kuartet terhadap kebiasaan sarapan ( $p$ value= $0,001)$, asupan energi sarapan ( $p$ value $=0,011$ ), asupan protein sarapan ( $p$ value $=0,008)$, dan pengetahuan gizi tentang sarapan ( $p$ value $=0,001$ ) sebelum dan sesudah dilakukan intervensi pada kelompok perlakuan dan kelompok kontrol.

\section{SARAN}

Berdasarkan penelitian ini, maka saran yang diberikan sebagai berikut penelitian ini menunjukkan adanya peningkatan mengenai kebiasaan sarapan, asupan energi dan protein sarapan dan pengetahuan gizi lebih besar menggunakan media kartu kuartet daripada metode ceramah, sehingga media kartu kuartet dapat diaplikasikan sebagai media dalam pembelajaran bagi institusi pendidikan dalam meningkatkan pengetahuan siswa sekolah dasar. Diperlukan penelitian lebih lanjut mengenai pendidikan gizi dengan media kartu kuartet sebagai media pendidikan dengan pengemasan media yang lebih menarik dan waktu yang lebih lama serta melibatkan peran sera guru dan orang tua.

\section{DAFTAR PUSTAKA}

1. Kemenkes RI. Kesehatan dalam Kerangka Sustainable Development Goals (SDGs). Jakarta, 2015. 
2. Sulistyoningsih, H. Gizi untuk Kesehatan Ibu dan Anak: Edisi Pertama. Graha Ilmu : Yogjakarta, 2011.

3. Kementerian Kesehatan RI. Riset Kesehatan Dasar. Laporan. Badan Penelitian dan Pengembangan Kesehatan. Kementerian Kesehatan RI : Jakarta, 2018.

4. Lawrence, Green., \& Marshall Kreuter. Health Program Planning : An Educational And Ecological Approach. 4 th ed. McGraw-Hill : New York, 2005.

5. Wahyuningsih, Ni Putu, Siti Rahayu Nadhiroh, Merryana Adriani. Media Pendidikan Gizi Nutrition Card Berpengaruh terhadap Perubahan Pengetahuan Makanan Jajanan Anak Sekolah Dasar. Media Gizi Indonesia. Surabaya.2015; 10(1):26-31.

6. Sutriyanto, Kristyawan, Ardini S Rakasanagara, Merry Wijaya. Pengaruh Permainan Kartu Kasugi terhadap Peningkatan Pengetahuan Perilaku Hidup Bersih dan Sehat pada Siswa. JSK. Bandung. 2016;1(4).

7. Sartika, Ratu Ayu Dewi. "Penerapan Komunikasi, Informasi, dan Edukasi Gizi terhadap Perilaku Sarapan Siswa Sekolah Dasar". Jurnal Kesehatan Masyarakat Nasional. 2012, Vol 7(2).

8. Nindrea, Ricvan Dana. Pengaruh Penyuluhan Gizi dengan Perubahan Perilaku Sarapan Pagi Siswa Sekolah Dasar. Jurnal Endurance. 2017, Vol 2(3).

9. Maduretno, Ida Sri, Nanik Setijowati, Nia Novita Wirawan. "Niat dan Perilaku Pemilihan Jajanan Anak Sekolah yang mendapat Pendidikan Gizi Metode Ceramah dan TGT". Indonesian Journal of Human Nutrition. 2015, Vol 2(1).

10. Anzarkusuma, Indah Suci, et al. Status Gizi Berdasarkan Pola Makan Anak Sekolah Dasar di Kecamatan Rajeg Tanggerang. Indonesian Journal of Human Nutrition. 2014, Vol 2(2).

11. Hardinsyah dan Muhammad Aries. Kebiasaan Sarapan Anak Indonesia berdasarkan Data Riskesdas 2010. Jurnal Gizi dan Pangan. Bogor. 2012.

12. Perdana, Fachruddin dan Hardinsyah. Analisis Jenis, Jumlah, dan Mutu Gizi Konsumsi Sarapan Anak Indonesia. Jurnal Gizi dan Pangan. 2013;8(1):39-46

13. Ethasari, Rossa Kurnia. Hubungan Antara Kebiasaan Sarapan dengan Kesegaran Jasmani dan Status Gizi pada Anak Sekolah Dasar di SDN Padangsari 02 Banyumanik. Skripsi. Semarang: Fakultas Kedokteran Universitas Diponegoro. 2014.

14. Gambir, Jurianto dan Nopriantini. Penerapan Model Edukasi Gizi terhadap Perilaku Sarapan pada Anak Sekolah Dasar. Jurnal Vokasi Kesehatan. 2018; 4(2):95-99. Pustika, Merlyana.
Hubungan Antara Asupan Energi dan Protein dari Sarapan Pagi dengan Prestasi Belajar Siswa di SDN Sumber III Surakarta. Naskah Publikasi. Surakarta: Universitas Muhammadiyah Surakarta. 2015.

15. Pustika, Merlyana. Hubungan Antara Asupan Energi dan Protein dari Sarapan Pagi dengan Prestasi Belajar Siswa di SDN Sumber III Surakarta. Naskah Publikasi. Surakarta: Universitas Muhammadiyah Surakarta. 2015.

16. Wahyuningsih, Ni Putu, Siti Rahayu Nadhiroh, Merryana Adriani. Media Pendidikan Gizi Nutrition Card Berpengaruh terhadap Perubahan Pengetahuan Makanan Jajanan Anak Sekolah Dasar. Media Gizi Indonesia. Surabaya.2015; 10(1):26-31.

17. Dina Fadhilah, Ninuk Sri Hartini, I Made Alit Gunawan. Efektifitas Penyuluhan tentang Sayuran Menggunakan Media "Kartu Sayuran" terhadap Peningkatan Pengetahuan Siswa Sekolah Dasar. Jurnal Nutrisia. Yogyakarta. 2017.

18. Khairunnisak. Penggunaan Media Kartu Sebagai Strategi Dalam Pembelajaran Membaca Permulaan: Studi Kasus di Madrasah Ibtidaiyah Negeri Rukoh, Banda Aceh. Jurnal Pencerahan. 2015.9(2): 66-82.

19. Kementrian Kesehatan RI. Pedoman Gizi Seimbang. 2014. 1-99 p.

20. Arikunto S. Prosedur Penelitian. Jakarta: Rineka Cipta; 2010. 